\title{
TRAIL sensitisation by arsenic trioxide is caspase- 8 dependent and involves modulation of death receptor components and Akt
}

\author{
E Szegezdi ${ }^{1,2}$, S Cahill', ${ }^{1,2}$ M Meyer ${ }^{1,2}$, M O'Dwyer $^{3}$ and A Samali ${ }^{* 1,2}$ \\ 'Department of Biochemistry, National University of Ireland,University Road, Galway, Ireland; ${ }^{2}$ The National Centre for Biomedical Engineering Science, \\ National University of Ireland, University Road, Galway, Ireland; ${ }^{3}$ Department of Haematology, University College Hospital Galway, Newcastle Road, \\ Galway, Ireland
}

The majority of leukaemic cells are resistant to apoptosis induced by tumour necrosis factor-related apoptosis-inducing ligand (TRAIL). Here, we show that sublethal concentrations of arsenic trioxide (ATO) specifically enhanced TRAIL-induced apoptosis in leukaemic but not in other tumour cell lines. The combination of ATO and TRAIL synergistically enhanced cleavage of caspase-8, which was blocked by the caspase inhibitor IETD.fmk as well as in cells deficient for caspase-8, suggesting a requirement for the deathinducing signalling complex. Arsenic trioxide led to increased cell surface expression of DR5 (death receptor 5), inhibition of the serine/threonine kinase Akt and downregulation of the short isoform of FLIP (FLICE-inhibitory protein, FLIPS). Inhibition of the phosphatidylinositol 3 kinase (PI3K) was equally efficient in sensitising leukaemic cells to TRAIL with similar effects on DR5 and FLIPS expression, suggesting that ATO may in part act through inhibition of the PI3K/Akt signalling pathway. These results indicate that the enhancement in TRAIL-mediated apoptosis induced by ATO is due to alteration in the levels of multiple components and regulators of the death receptor-mediated pathway. These findings offer a promising and novel strategy involving a combination of TRAIL and ATO, or more specific Akt inhibitors in the treatment of various haematopoietic malignancies.

British Journal of Cancer (2006) 94, 398-406. doi:I0.I038/sj.bjc.6602954 www.bjcancer.com

Published online 24 January 2006

(c) 2006 Cancer Research UK

Keywords: arsenic trioxide; TRAIL; Akt; leukaemia; DR5; FLIP

The outcome of adult patients with acute leukaemia has changed little over the past 20 years, especially in older patients $(>60$ years) in whom intensive chemotherapy is frequently inappropriate and survival poor. Development of less-toxic, targeted approaches is clearly necessary. One such emerging anticancer agent is the tumour necrosis factor-related apoptosis-inducing ligand (TRAIL). Tumour necrosis factor-related apoptosis-inducing ligand is a member of the TNF death ligand family, which can interact with four distinct membrane-bound receptors (DR4/ TRAIL-R1, DR5/TRAIL-R2, DcR1/TRAIL-R3 and DcR2/TRAIL-R4) (Wiley et al, 1995; Ashkenazi and Dixit, 1999). DR4 and DR5 contain a conserved cytoplasmic region called the death domain (DD) that is required for TRAIL-induced apoptosis. DcR1 does not have a cytoplasmic domain, whereas DcR2 contains a truncated DD motif (Ashkenazi and Dixit, 1999). Thus, DcR1 and DcR2 act as decoy receptors, and ligation of only DR4 or DR5 initiates apoptosis.

Binding of TRAIL to DR4 or DR5 leads to receptor trimerisation and assembly of the death-inducing signalling complex (DISC). Caspase- 8 is recruited to the DISC where it becomes activated (Ashkenazi and Dixit, 1999; MacFarlane, 2003). Subsequent events can follow two apoptotic-signalling pathways. In the first scenario (type I cells), caspase-8 directly activates effector caspases (caspase-3, -6, -7), while in type II cells, caspase- 8 engages the mitochondrial pathway by activating Bid (Sartorius et al, 2001).

*Correspondence: Dr A Samali; E-mail: afshin.samali@nuigalway.ie Revised 28 November 2005; accepted 16 December 2005; published online 24 January 2006
Tumour necrosis factor-related apoptosis-inducing ligand is an attractive antineoplastic agent as it preferentially induces apoptosis in transformed cells, with little effect on normal cells (Lawrence et al, 2001; Almasan and Ashkenazi, 2003). Additionally, TRAIL may overcome drug resistance due to dysfunction of the p53 pathway or overexpression of Bcl-2 family members (Walczak et al, 2000; Nagane et al, 2001). However, response to TRAIL is highly variable with resistance seen in many cancer types, including leukaemia (Ehrhardt et al, 2003). Potential mechanisms of resistance include poor expression of DR4 and/or DR5 or increased expression of decoy receptors and c-FLIP (FLICE-inhibitory protein) (Sheridan et al, 1997; Jin et al, 2004; Ricci et al, 2004). In type II cells due to the requirement for intrinsic pathway amplification, TRAIL resistance also can be mediated at the level of the mitochondria by Bcl-2 and Bcl- $\mathrm{X}_{\mathrm{L}}$ (Korsmeyer, 1992). Finally, overexpression of inhibitor of apoptosis proteins (IAP) can prevent TRAIL-induced apoptosis through inhibition of effector caspases (caspase-3, -6 and -7) (Aggarwal et al, 2004). Notably, the expression of these different antiapoptotic proteins may be regulated by several different signal transduction pathways including Akt, NF- $\kappa \mathrm{B}$ and p53, which are frequently activated in leukaemias (Shankar and Srivastava, 2004). Strategies to overcome these mechanisms of resistance are the subject of intensive investigation. A variety of anticancer modalities including cytotoxic chemotherapy, radiation and novel therapies were shown to have additive or synergistic effects with TRAIL (Sayers et al, 2003; Ganten et al, 2004; Inoue et al, 2004; Rosato et al, 2004). However, in most of these studies, no mechanistic insight was provided.

Based on a recent report demonstrating synergy between arsenic trioxide (ATO) and TRAIL in myeloma cells, we were interested in 
exploring the potential of ATO as a TRAIL-sensitising agent in leukaemic cells (Liu et al, 2003). Arsenic trioxide has pleiotropic mechanisms of action. Differential effects with respect to induction of differentiation and apoptosis have been described, which appear to be dose dependent (Chen et al, 1996). At low, clinically achievable concentration, ATO has demonstrated marked activity in acute promyelocytic leukaemia (APL) with little toxicity (Niu et al, 1999; O'Dwyer et al, 2002). In other haematological malignancies however, as a single agent, ATO has only a modest activity, although it may have a greater role in combination with other drugs (Evens et al, 2004).

We examined a selection of tumour cell lines, (including three leukemic cell lines) looking for evidence of synergy between ATO and TRAIL and specifically, to identify the cellular mechanisms underlying this effect. In all three leukaemic cell lines tested, ATO augmented TRAIL-induced cell death. This could be blocked by inhibition or absence of caspase- 8 suggesting a requirement for the DISC complex. Arsenic trioxide increased cell surface expression of DR5, inhibited phosphorylation of Akt and led to downregulation of the short isoform of FLIP $\left(\right.$ FLIP $\left._{S}\right)$. Inhibition of the PI3K was equally efficient in sensitising leukaemic cells to TRAIL with similar effects on DR5 and $\mathrm{FLIP}_{\mathrm{S}}$ expression, suggesting that ATO may act through inhibition of the PI3K/Akt signalling pathway. These results point out that the combination of TRAIL and ATO, or more specific Akt inhibitors may be valuable in the treatment of various haematopoietic malignancies.

\section{MATERIALS AND METHODS}

\section{Cell culture and treatments}

Jurkat, caspase-8-deficient Jurkat (Juo et al, 1998), ML-1, K562, Raji and Colo205 cells were cultured in RPMI medium. PC3, HeLa, cells were cultured in DMEM medium. Both media were supplemented with $10 \%$ foetal bovine serum, $2 \mathrm{~mm}$ glutamine, $50 \mathrm{U} \mathrm{ml}^{-1}$ penicillin and $5 \mathrm{mg} \mathrm{ml}^{-1}$ streptomycin, RPMI medium was also supplemented with $1 \mathrm{~mm}$ Na-pyruvate. To induce apoptosis, cells were treated with various concentrations of recombinant TRAIL (soluble TRAIL (aa 114-281) was a kind gift from Professor Wim J Quax, University of Groningen, Groningen, the Netherlands) in the presence or absence of increasing concentration of ATO $\left(100-1000 \mathrm{ng} \mathrm{ml}^{-1}, 0.5-5 \mu \mathrm{M}\right)$ for the indicated time periods. The PI3K inhibitor LY294002 (Calbiochem, Schwalbach, Germany) and the caspase inhibitor IETD.fmk (Enzyme Systems Products, Livermore, CA, USA) were added $1 \mathrm{~h}$ prior to treatment with TRAIL at a final concentration of $20 \mu \mathrm{M}$. All other reagents were from Sigma-Aldrich, St Louis, MO, USA, unless indicated otherwise.

\section{Western blot analysis}

Cells were lysed in a buffer containing $20 \mathrm{~mm}$ HEPES, pH 7.5, $350 \mathrm{~mm} \mathrm{NaCl}, 1 \mathrm{~mm} \mathrm{MgCl}_{2}, 0.5 \mathrm{~mm}$ EDTA, $0.5 \mathrm{~mm}$ EGTA, 1\% NP-
40, $0.5 \mathrm{~mm}$ dithiothreitol (DTT), $100 \mu \mathrm{M}$ PMSF (phenylmethanesulphonyl fluoride), $2 \mu \mathrm{g} \mathrm{ml}^{-1}$ pepstatin A, $25 \mu \mathrm{M}$ ALLN, $2.5 \mu \mathrm{g} \mathrm{ml}^{-1}$ aprotinin and $10 \mu \mathrm{m}$ leupeptin. Proteins were separated by electrophoresis on $10 \%$ SDS-polyacrylamide gels and then transferred onto nitrocellulose membranes. After blocking in 5\% nonfat milk, $0.05 \%$ Tween-20 in PBS, blots were incubated with 1:1000 dilution of antibodies to caspase-8, P-Akt (Ser 473), Akt (all from Cell Signaling Technology, Danvers, MA, USA), c-FLIP (Stressgen, Victoria, BC, Canada) and 1:500 dilution of rabbit polyclonal antibody against $\beta$-actin (Sigma, St Louis, MO, USA). The appropriate horseradish peroxidase-conjugated goat secondary antibodies (Pierce, Rockford, IL, USA) were used at a 1:5000 for primary antibodies from Cell Signaling Technologies and at a $1: 10000$ dilution for all other antibodies. Protein bands were detected with Super Signal Ultra Chemilumiescent Substrate (Pierce) on X-ray film (Agfa, Mortsel, Belgium).

\section{Haematoxylin-Eosin staining and microscopy}

After treatments, cells were spun onto microscope slides, fixed in methanol for $5 \mathrm{~min}$ at room temperature and were stained by immersion in Harris haematoxylin solution for $5 \mathrm{~min}$ followed by $1 \mathrm{~min}$ immersion in Eosin Y. The slides were mounted using DPX. Phase contrast images were taken from 15 randomly chosen areas per sample using $400 \times$ overall magnification (Zeiss S100 Microscope). For data acquisition, the AQM acquisition manager program was used.

\section{Caspase activity assay}

Cells were harvested by centrifuging at $450 \mathrm{~g}$ for $5 \mathrm{~min}$. After two washes in PBS, duplicate samples of $25 \mu$ l were transferred to a microtitre plate and snap-frozen over liquid nitrogen. To initiate the reaction, $50 \mu \mathrm{m}$ of the caspase substrate Ac-Ile-Glu-Thr-Asp- $\alpha$ (4-methyl-coumaryl-7-amide) (IETD-AMC) (Peptide Institute Inc., Osaka, Japan) in assay buffer (100 mM HEPES, $10 \%$ sucrose, $5 \mathrm{~mm}$ DTT, $0.0001 \%$ NP-40 and 0.1\% 3-[(3-cholamidopropyl) dimethylammonio] propane-1-sulphonic acid (CHAPS), pH 7.25) was added to the cell lysates. Liberated AMC was measured at $37^{\circ} \mathrm{C}$ kinetically every $60 \mathrm{~s}$, for 25 repeats on a Wallac Victor ${ }^{2}$ plate reader using excitation and emission wavelengths of 355 and $460 \mathrm{~nm}$, respectively. Enzyme activity was expressed as nanomole $\mathrm{AMC}$ released per minute per $\mathrm{mg}$ of protein.

\section{MTT assay}

MTT dye $\left(250 \mu \mathrm{g} \mathrm{ml}^{-1}\right)$ was added to control and treated cells and incubated for $3 \mathrm{~h}$ at $37^{\circ} \mathrm{C}$. The reaction was stopped and the blue formazan precipitate formed was dissolved using 20\% SDS in $50 \%$ dimethylformamide. The colour intensity was measured at $550 \mathrm{~nm}$ on a Wallac Victor ${ }^{2}$ plate reader. The control value corresponding to untreated cells was taken as $100 \%$ and the viability of treated samples was expressed as a percentage of the control.

Table I Semiquantitative representation of TRAIL and ATO sensitivity of tested cell lines

\begin{tabular}{|c|c|c|c|}
\hline Cell line & Origin & TRAIL sensitivity & Synergism with ATO \\
\hline PC3 & Prostate adenocarcinoma & +++ & + \\
\hline HeLa & Cervical adenocarcinoma & + & + \\
\hline Colo205 & Colon adenocarcinoma & +++++ & + \\
\hline Raji & Burkitt's lymphoma & + & + \\
\hline ML-I & Acute myeloid leukaemia & +++ & +++++ \\
\hline K562 & Chronic myelogenous leukemia & + & +++++ \\
\hline Jurkat & Acute T-cell leukaemia & ++ & +++++ \\
\hline
\end{tabular}



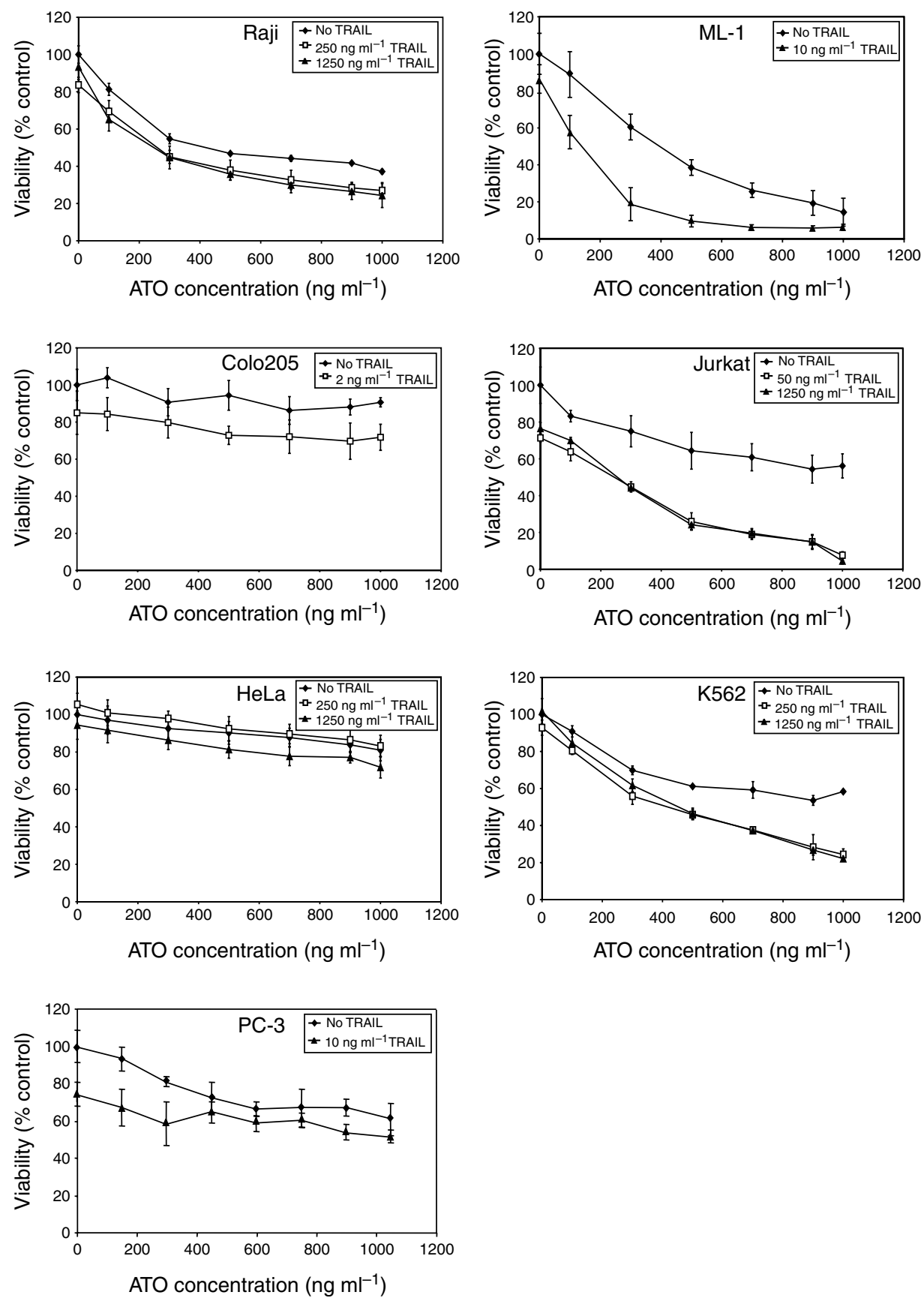

Figure I Tumour necrosis factor-related apoptosis-inducing ligand and ATO has synergistic cytotoxic effect in leukaemic cells. Seven tumour cell lines were treated with TRAIL in the presence of increasing concentration of ATO for $24 \mathrm{~h}$. Cell viability was measured by MTT assay. The graphs show the average cell viability \pm s.d. from three independent experiments expressed as percentage of untreated cells.

\section{Apoptosis detection assay}

Cells were treated with TRAIL and ATO for 6-12h and PS (phosphatidyl serine) exposure was measured using annexin-VFITC (IQ Corporation, Groningen, The Netherlands) as described earlier (Concannon et al, 2005). Briefly, cells were collected by centrifugation at $350 \mathrm{~g}$, washed once in ice-cold calcium buffer (10 mM HEPES/NaOH, pH 7.4, $140 \mathrm{~mm} \mathrm{NaCl}, 2.5 \mathrm{mM} \mathrm{CaCl}_{2}$ ) and incubated with annexin V-FITC for $15 \mathrm{~min}$ on ice. A wash step in calcium buffer was carried out prior to acquisition on a
FacsCalibur flow cytometer (Becton Dickinson, Franklin Lakes, NJ, USA).

\section{Cell surface expression of TRAIL receptors}

Cells were washed twice in PBS containing $1 \%$ BSA and then incubated with monoclonal antibodies to DR4, DR5, DcR1 and DcR2 (Alexis, Lausen, Switzerland) for $40 \mathrm{~min}$. After two wash steps with PBS/BSA, anti-mouse IgG-FITC (Sigma) secondary 
A

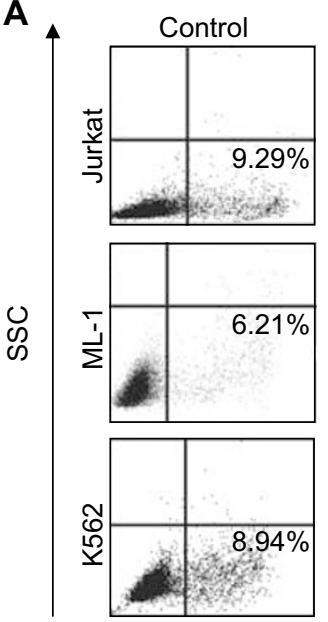

TRAIL
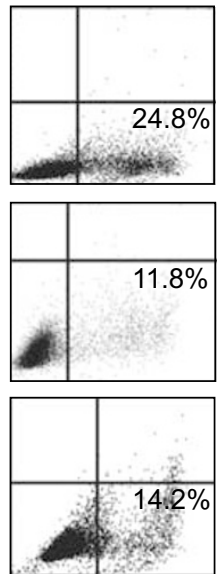

ATO
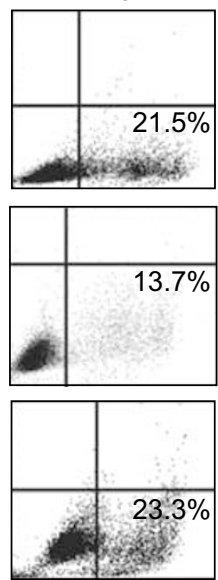

TRAIL+ATO
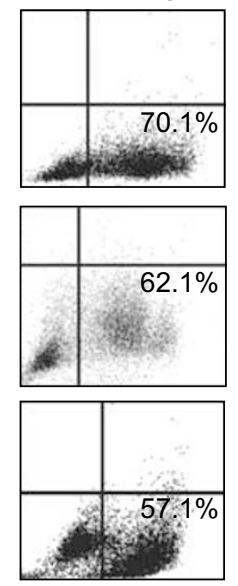

Annexin $\mathrm{V}$

B

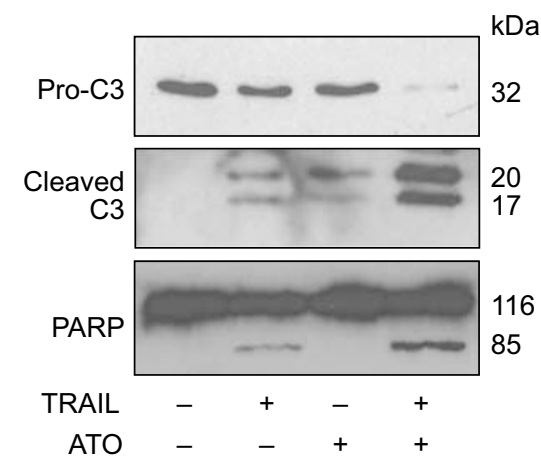

C

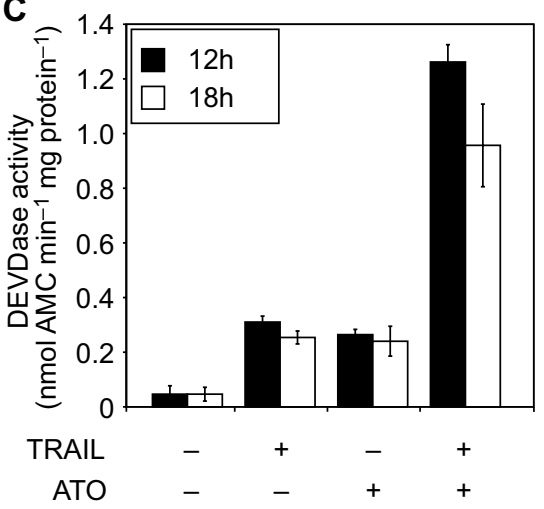

Figure 2 Combined treatment with TRAIL and ATO has synergistic apoptosis-inducing effect. Cells were treated with sublethal dose of TRAIL (Jurkat: $\left.50 \mathrm{ng} \mathrm{ml}^{-1}, \mathrm{ML-l}: 10 \mathrm{ng} \mathrm{ml}^{-1}, \mathrm{~K} 562: 250 \mathrm{ng} \mathrm{ml}^{-1}\right)$ in the presence or absence of ATO $\left(500 \mathrm{ng} \mathrm{ml}^{-1}\right)$. (A) Apoptotic cell death was measured I2 $\mathrm{h}$ post treatment by annexin $V$ staining. One representative dot plot image from three independent experiments is shown. (B) Western blot analysis of procaspase-3 and PARP cleavage in Jurkat cells treated with TRAIL and ATO for $10 \mathrm{~h}$. The figure shows one representative picture of three independent experiments. (C) DEVDase activity in TRAIL- and ATO-treated Jurkat cells. DEVDase activity was measured in whole-cell lysates with a kinetic assay. Enzyme activity was expressed in nmole AMC released per minute by I mg total cellular protein. The chart represents the result of three independent experiments \pm s.d.

antibody was added for $30 \mathrm{~min}$. All incubations were carried out at room temperature. Negative controls contained only secondary antibody. Cell surface expression was analysed by a FacsCalibur flow cytometer.

\section{RESULTS}

\section{Synergistic cytotoxic effect of TRAIL and ATO on leukaemic cells}

We examined whether treatment with sublethal doses of ATO can sensitise tumour cells to TRAIL-induced apoptosis. A panel of seven human cancer cell lines was tested, including three adenocarcinomas, a B-cell lymphoma and three leukaemias. Treatment with TRAIL alone revealed varying sensitivity between the different cell types. The most TRAIL-sensitive of the seven cell lines was the Colo205 colon adenocarcinoma cell line, where $10 \mathrm{ng} \mathrm{ml}^{-1}$ TRAIL caused almost $100 \%$ cell death within $24 \mathrm{~h}$. The myeloid leukaemia ML-1 and the prostate adenocarcinoma PC3 cells were also sensitive but required $200 \mathrm{ng} \mathrm{ml}^{-1}$ TRAIL over $24 \mathrm{~h}$ for $90 \%$ cell death. In the remaining cell lines, TRAIL could not induce more than $20 \%$ cell death over $24 \mathrm{~h}$ even at the highest concentration used $\left(1.25 \mu \mathrm{g} \mathrm{ml}^{-1}\right)$ (Table 1).

To test the effect of ATO on TRAIL sensitivity of these tumour cells, for each cell line the lowest TRAIL concentration that caused $10-20 \%$ cell death was determined. Using this TRAIL concentration, the cells were treated with increasing concentration of ATO $\left(100-1000 \mathrm{ng} \mathrm{ml}^{-1}\right.$, i.e. $\left.0.5-5 \mu \mathrm{M}\right)$ for $24 \mathrm{~h}$ and cell viability was determined with MTT assay (Figure 1). In case of the TRAILresistant cell lines, the highest TRAIL concentration $\left(1.25 \mu \mathrm{g} \mathrm{ml}^{-1}\right)$ was also tested, but no difference was observed (Figure 1). Of the seven cell lines, none of the adenocarcinomas responded to ATO treatment with increased TRAIL sensitivity (Table 1). However, all three leukaemia cell lines (Jurkat, ML-1 and K562) showed enhanced cell death in response to the combined treatment. Phosphatidyl serine exposure measured by the extent of annexin $\mathrm{V}$ binding confirmed the synergistic death-inducing effect of TRAIL and ATO in the three leukaemic cell lines. In Jurkat cells, $12 \mathrm{~h}$ treatment with TRAIL or ATO induced $15 \%$ and $12 \%$ annexin V positivity, respectively. However, the combined treatments led to $69 \%$ positivity in $12 \mathrm{~h}$. Similar results were obtained in ML-1 and K562 cells (Figure 2A). Cell death induced by the combined treatment displayed features of apoptosis, including blebbing, 

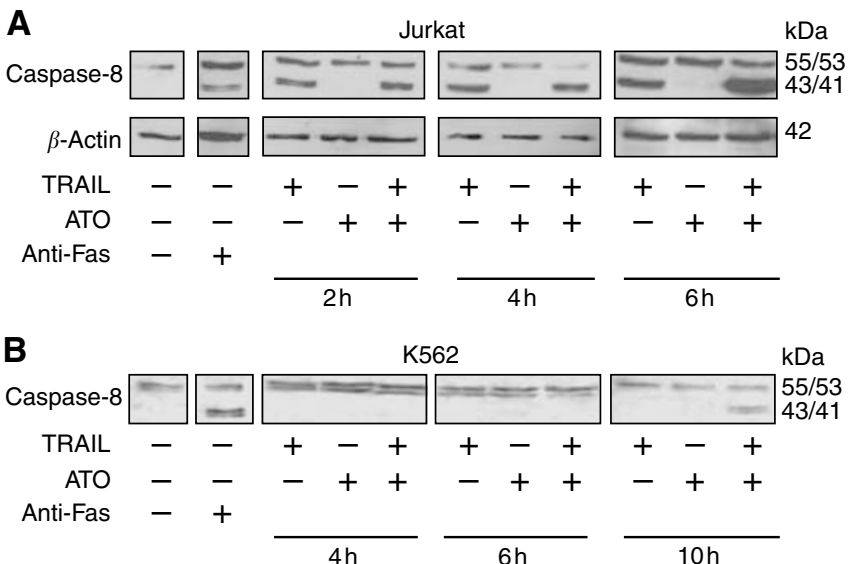

C

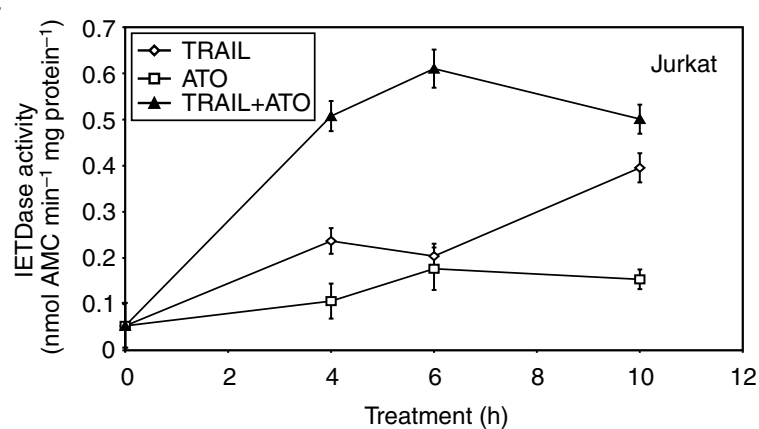

D

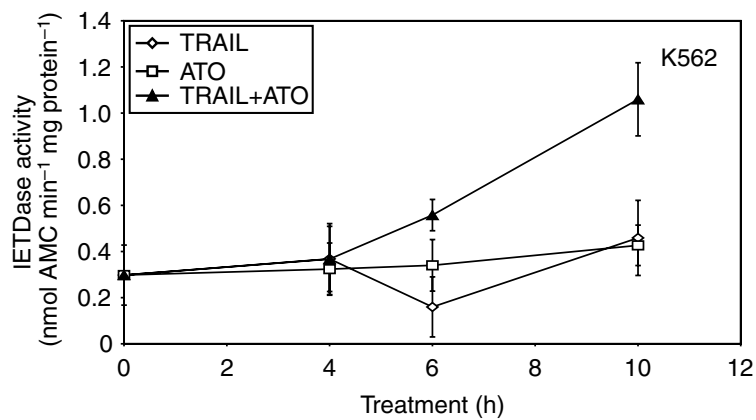

Figure 3 Combined TRAIL and ATO treatment leads to increased procaspase- 8 cleavage and activation. Jurkat and $\mathrm{K} 562$ cells were treated with TRAIL (50 and $250 \mathrm{ng} \mathrm{ml}^{-1}$, respectively), ATO $\left(500 \mathrm{ng} \mathrm{ml}^{-1}\right.$ ) or with both for the indicated times. Pro-caspase-8 cleavage $(\mathbf{A}, \mathbf{B})$ and IETDase activity $(\mathbf{C}, \mathbf{D})$ were measured in Jurkat $(\mathbf{A}, \mathbf{C})$ and $\mathrm{K} 562$ (B, D) cell lysates. In part A, $\beta$-actin was used as a loading control. Enzyme activity was expressed as nmole AMC released per minute per $\mathrm{mg}$ total cellular protein. The graphs show the average \pm s.d. of three independent experiments.

nuclear condensation (data not shown), pro-caspase-3 processing and activation, as well as cleavage of the caspase- 3 substrate protein PARP (Figure $2 \mathrm{~B}$ and $\mathrm{C}$ ).

\section{Sensitisation by ATO is caspase- 8 dependent}

To delineate the mechanism by which low-dose ATO modifies sensitivity to TRAIL, activation of pro-caspase- 8 in Jurkat and K562 cells was examined by following pro-caspase- 8 cleavage with Western blotting (Figure 3A and B) and by a fluorescent IETDase assay (Figure $3 \mathrm{C}$ and D). In Jurkat cells, treatment with TRAIL alone induced some pro-caspase- 8 processing, which was detectable after $2 \mathrm{~h}$ treatment (Figure $3 \mathrm{~A}$ ). Longer incubation with TRAIL led only to a marginal increase in pro-caspase- 8 processing. Combined treatment with TRAIL and ATO induced pro-caspase- 8
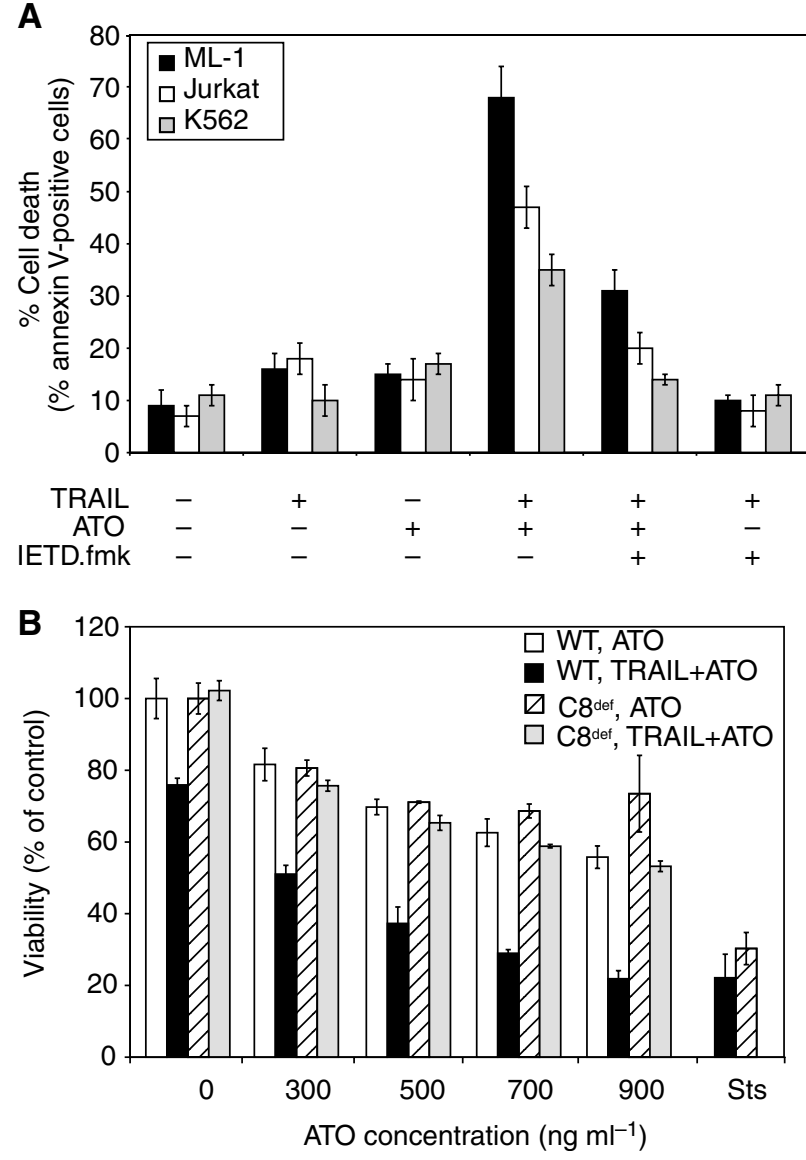

Figure 4 Inhibition or deficiency of caspase-8 prevents cell death induced by combined TRAIL + ATO treatment. (A) Cells were treated with TRAIL (Jurkat: $50 \mathrm{ng} \mathrm{ml}^{-1}, \mathrm{ML}^{-1}: 10 \mathrm{ng} \mathrm{m}^{-1}, \mathrm{~K} 562: 250 \mathrm{ng} \mathrm{ml}^{-1}$ ), ATO $\left(500 \mathrm{ng} \mathrm{ml}^{-1}\right)$ or both in the presence or absence of IETD.fmk $(20 \mu \mathrm{M})$. Cell death was measured by flow cytometry after annexin $\vee$ staining. Results are represented as average cell death \pm s.d. of three independent experiments (B) Caspase-8-expressing (WT) and caspase-8-deficient (C8 ${ }^{\text {def }}$ ) Jurkat cells were treated with increasing doses of ATO with or without TRAIL $\left(50 \mathrm{ng} \mathrm{m}^{-1}\right)$. Viability was measured by MTT assay. The graph shows the average of two independent experiments \pm s.d.

processing similar to TRAIL alone at $2 \mathrm{~h}$; however, as the incubation time increased, a much more pronounced, almost complete processing of pro-caspase- 8 was detectable (Figure $3 \mathrm{~A}$ ). In addition to the $\mathrm{p} 43 / \mathrm{p} 41$ cleavage product, the fully processed p18 caspase- 8 subunit was also detectable in the combined treatments (data not shown), indicating the lack of $\mathrm{c}^{-F_{L} \mathrm{P}_{\mathrm{L}}-}$ mediated inhibition of caspase-8 (Krueger et al, 2001). Measurement of IETDase activity reflected the same pattern with high enzyme activity detectable only in the combination treatment peaking at $6 \mathrm{~h}$ of treatment (Figure 3C). In K562 cells, TRAIL or ATO alone failed to induce detectable pro-caspase- 8 processing or activity over the $10 \mathrm{~h}$ incubation time (Figure 3B and D). Combined treatment with TRAIL and ATO for $10 \mathrm{~h}$, however, induced pro-caspase- 8 cleavage and a pronounced IETDase activity.

In order to examine the requirement of caspase- 8 in the process, we used two approaches. Prior to treatment with TRAIL and ATO, ML-1, K562 and Jurkat cells were treated with the caspase inhibitor IETD.fmk, which is thought to preferentially target caspase- 8 and -10. Pretreatment with IETD.fmk partially prevented the synergistic action of TRAIL and ATO in all the three cell lines tested (Figure 4A). In the second approach, we used a caspase-8-deficient 
Jurkat cell line. In these cells, $24 \mathrm{~h}$ treatment with ATO had minor cytotoxic effect, similar to that found in wild-type Jurkat cells. Addition of TRAIL in combination with ATO however, caused no increase in cell death, providing compelling evidence for a caspase8-dependent action of the combined TRAIL and ATO treatment (Figure 4B). Requirement for caspase-8 further proves that ATO, at the concentrations used, primarily acts to reactivate the TRAIL death pathway, not as a TRAIL-independent cytotoxic stimulus.

\section{ATO increases DR5 cell surface expression}

As TRAIL and ATO enhanced caspase- 8 activation and their synergistic action was caspase- 8 dependent, it prompted us to identify whether components of the DISC complex are affected by ATO. The cell surface expression of DR4, DR5 and the two decoy receptors, DcR1 and DcR2, was assessed in Jurkat cells. Although there was no change in the expression of the two decoy receptors and DR4, the cell surface expression of DR5 was increased after $6 \mathrm{~h}$ treatment with ATO (Figure 5A).

\section{ATO affects phosphorylation state of Akt}

Akt is a serine/threonine kinase, a target of the phosphatidylinositol 3 kinase (Brazil et al, 2002). It has a strong antiapoptotic and proliferative function and is known to be activated (phosphorylated) in several leukaemias. Jurkat cells also have considerable basal Akt activity. Examination of the effect of ATO on Akt phosphorylation in Jurkat cells by Western blotting revealed that ATO treatment resulted in a rapid $(4-6 \mathrm{~h})$ and significant decrease in Akt phosphorylation. The decrease in the level of phosphorylated Akt (P-Akt) was due to dephosphorylation of Akt, rather then a reduction in total Akt protein levels (Figure 5B).

In order to address the possible link between Akt and TRAIL sensitivity, ATO was replaced with the PI3K inhibitor LY294002 $(20 \mu \mathrm{M})$ in the combination treatment with TRAIL. Pretreatment of cells with LY294002 for $1 \mathrm{~h}$ also led to increased TRAIL responsiveness. Cell death measured by annexin $\mathrm{V}$ staining (Figure 6A) synergistically increased after combined treatment and cells showed features of apoptosis, including typical morphological changes (data not shown), pro-caspase- 3 processing and activation (Figure $6 \mathrm{~B}$ and $\mathrm{C}$ ). Akt phosphorylation was also examined after treatment with the PI3K inhibitor LY294002 in order to compare the Akt inhibiting potential of ATO and LY294002. Treatment with LY294002 caused rapid and complete dephosphorylation of Akt in $4 \mathrm{~h}$ (Figure 6E). Arsenic trioxide also induced similar, although not complete, inhibition of Akt after $4 \mathrm{~h}$ (Figure 6E).

Since treatment with ATO increased cell surface expression of DR5, we examined if treatment with LY294002 mimicked this effect. A treatment of Jurkat cells with LY294002 for $4 \mathrm{~h}$, although to a lesser extent, also increased cell surface expression of DR5, without affecting DR4 (Figure 6D). A possible alteration in c-FLIP, a downstream target of Akt and a common inhibitor of TRAILinduced apoptosis was also examined (Figure 6E). We found that treatment with either ATO or LY294002 caused a rapid and pronounced drop in the expression of the short form of c-FLIP, detectable after $4 \mathrm{~h}$ treatment, pointing to a possible common mechanism of action. Together, these data suggest that the mechanism by which ATO enhances TRAIL sensitivity involves inhibition of Akt and primarily targets components of the DR5 DISC complex.

\section{DISCUSSION}

Elemental arsenic has been used for centuries in medication and arsenic was the first successful treatment for CML. Recently, the trioxide derivative of arsenic has been shown to have marked
A

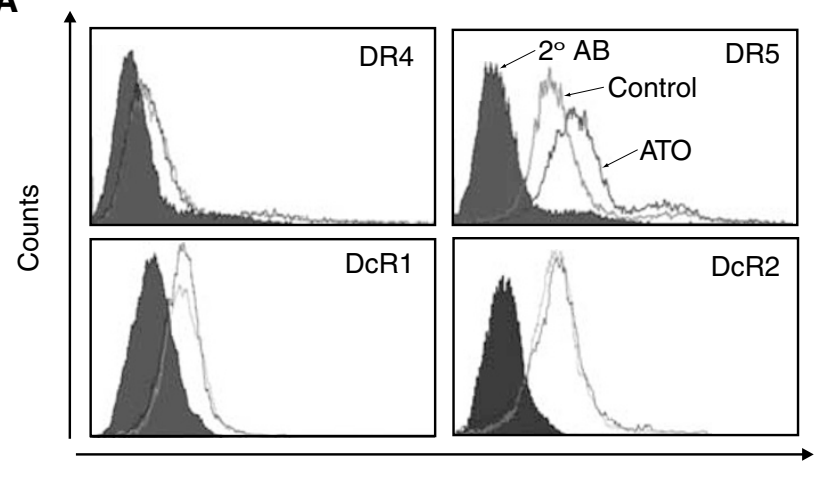

TRAIL receptor

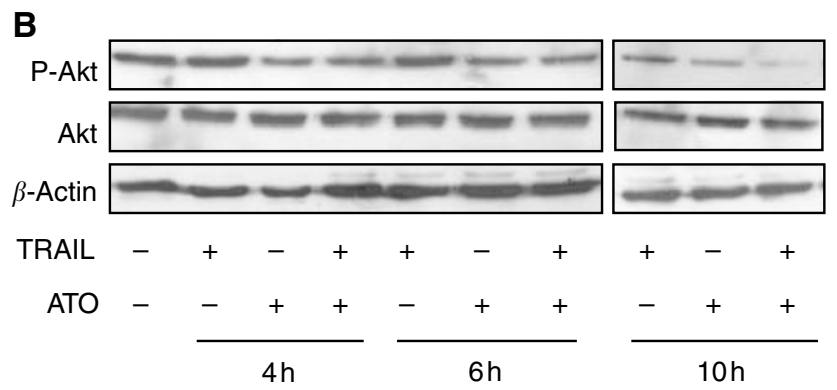

Figure 5 Aarsenic trioxide affects Akt phosphorylation and DR5 cell surface expression. (A) Flow cytometric analysis of cell surface expression of TRAIL receptors DR4, DR5, DCRI and DCR2 in Jurkat cells after treatment with $500 \mathrm{ng} \mathrm{ml}^{-1}$ ATO for $6 \mathrm{~h}$. (B) Western blot analysis of phosphorylated Akt and total cellular Akt in Jurkat cells treated with $50 \mathrm{ng} \mathrm{ml}^{-1}$ TRAIL in the presence or absence of $500 \mathrm{ng} \mathrm{ml}^{-1}$ ATO for the indicated times. $\beta$-Actin was used as a loading control. In all cases, one representative image of three independent experiments is shown.

activity against relapsed APL inducing complete remission in $87 \%$ of patients with only minimal side effects (Soignet et al, 2001; Douer and Tallman, 2005). The multiple mechanisms of action of ATO suggest that it may have antitumour activity in malignancies other than APL and that it may be used in combination with other agents. In the present study, we examined the mechanism of ATOmediated sensitisation of cancer cells to TRAIL-induced apoptosis. We found that ATO specifically enhanced TRAIL-mediated cell death in leukaemic cells, but not in other cancer cell types. Our results indicate that the mechanism involves inhibition of the PI3K/Akt pathway, and modulation of the TRAIL receptor DISC components FLIP $_{\mathrm{S}}$ and DR5.

Studying the mechanism of ATO-mediated sensitisation revealed that combined treatment of Jurkat and K562 cells with TRAIL and ATO led to increased processing and activation of pro-caspase-8. The synergistic apoptosis-inducing effect appeared to be caspase-8 dependent, as IETD.fmk-treated and caspase-8deficient cells were resistant to combined TRAIL and ATO-induced apoptosis. As in most haematopoietic cells, TRAIL induces the type I pathway, that is, mitochondrial amplification is not required, and our findings suggested that the synergistic effect is at the level of the DISC. To understand this effect further, we examined the components of the DISC and observed early upregulation of DR5 along with downregulation of c-FLIP. Upregulation of DR5 has been reported following treatment of different cancer cell lines with a variety of anticancer agents, where both p53-dependent and -independent mechanisms are recognised (Wang and El-Deiry, 2003; Insinga et al, 2005). Following treatment with ATO, myeloma cell lines with varying p53 status, all showed upregulation of DR4 and DR5 and synergy with TRAIL 
A

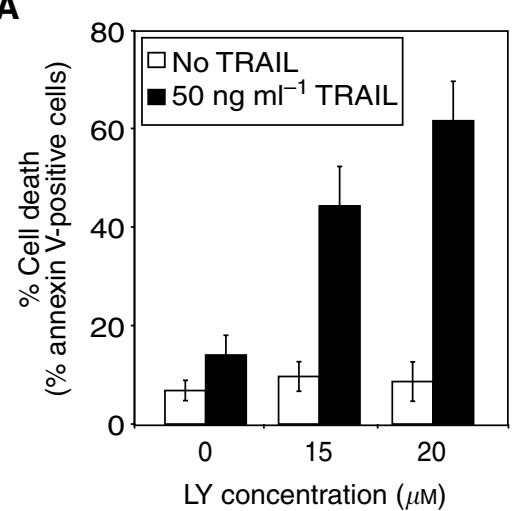

C

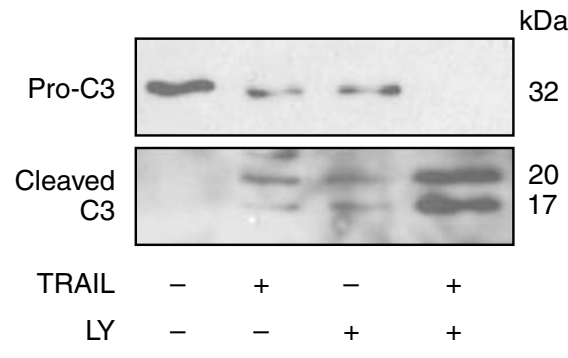

E

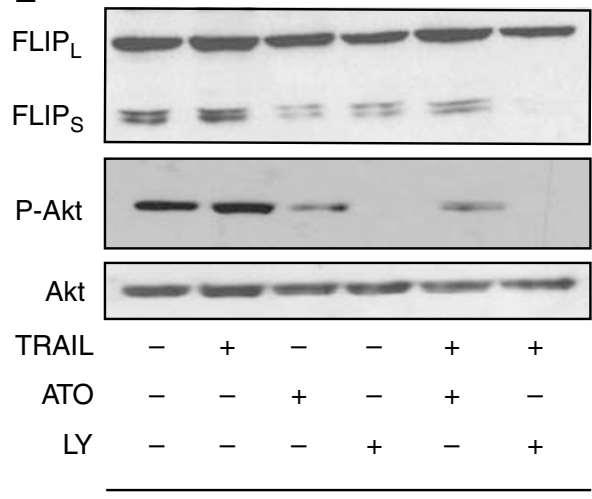

$4 \mathrm{~h}$

\section{B}

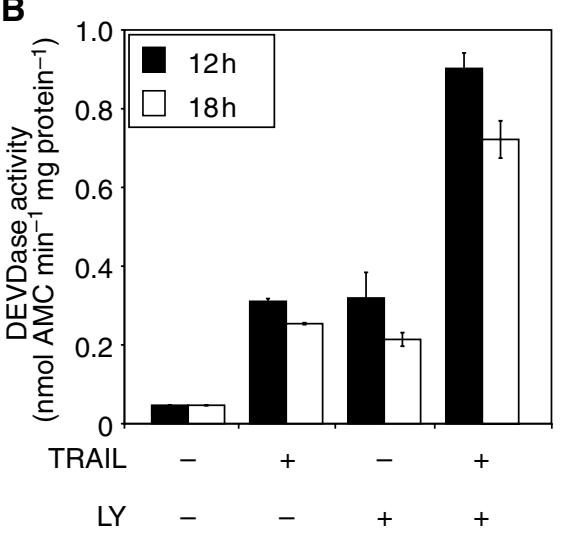

D

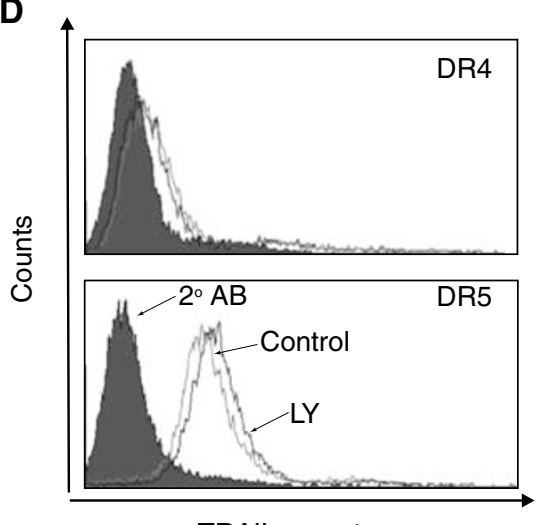

TRAIL receptor

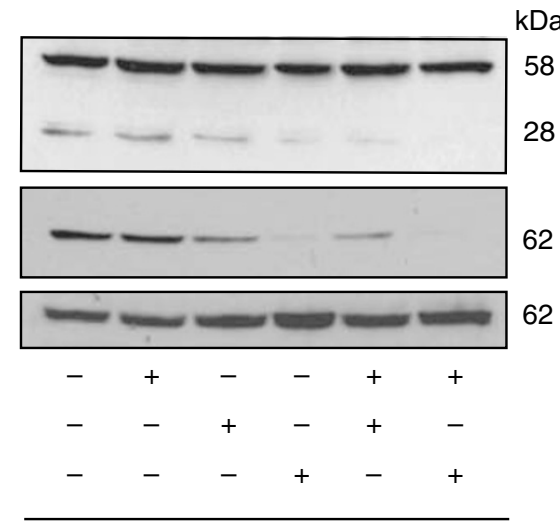

$10 \mathrm{~h}$

Figure 6 Inhibition of Akt signalling mimics the effect of ATO in Jurkat cells. Cells were treated with the PI3K inhibitor LY294002 (20 $\mu \mathrm{M})$ I h prior to treatment with TRAIL for $12 \mathrm{~h}$. Cell death was assessed by FACS analysis of annexin V-stained cells. The graph shows the average values of three independent experiments \pm s.d. (B) DEVDase activity in cells treated with TRAlL, ATO or both for the indicated times. DEVDase activity was measured in whole-cell lysates with a kinetic assay. Enzyme activity was expressed as nmole AMC released per minute by I mg total cellular protein. The chart represents the result of three independent experiments \pm s.d. (C) Western blot analysis of pro-caspase-3 cleavage in lysates of Jurkat cells treated with TRAlL $\left(50 \mathrm{ng} \mathrm{ml}^{-1}\right)$, ATO $\left(500 \mathrm{ng} \mathrm{ml}^{-1}\right)$ and TRAIL + ATO for $10 \mathrm{~h}$. The figure shows one representative picture from three independent experiments. (D) FACS analysis of DR4 and DR5 cell surface expression after $5 \mathrm{~h}$ treatment with LY294002 (20 $\mu \mathrm{M})$. The histograms are representatives of at least three independent experiments. (E) Western blot analysis of phosphorylated Akt, Akt and c-FLIP following treatment with $20 \mu \mathrm{M} \mathrm{LY294002} \mathrm{or} 500 \mathrm{ng} \mathrm{ml}^{-1}$ ATO in the presence or absence of $50 \mathrm{ng} \mathrm{ml}^{-1}$ TRAlL for the times indicated. The figure is one representative of three independent experiments.

(Akay and Gazitt, 2003; Liu et al, 2003). Since in Jurkat cells p53 is mutated, our data confirm that p53 is not required for ATOmediated surface induction of DR5 (Cheng and Haas, 1990; Trepel et al, 1997).

The observed decline in c-FLIP levels following ATO is particularly interesting. c-FLIP exists in various isoforms, the best-characterised are c-FLIP long $\left(\mathrm{c}^{-F_{L I P}}\right)_{\mathrm{L}}$ ) and c-FLIP short $\left(\mathrm{c}-\right.$ FLIP $\left._{\mathrm{S}}\right)$. c-FLIP has homology to caspases-8, and is able to inhibit apoptosis by acting as a competitive antagonist of caspase- 8 (Irmler et al, 1997). Overexpression and knock down studies as well as reported correlations between c-FLIP levels and reduced sensitivity to apoptosis implicate c-FLIP as a key inhibitor of death 
receptor-induced apoptosis (Ganten et al, 2004; Sharp et al, 2005). In Jurkat cells, ATO treatment caused a pronounced decrease in $\mathrm{c}^{- \text {FLIP }_{S}}$ expression, detectable very early, after $4 \mathrm{~h}$ treatment. Decreased c-FLIP levels together with increased DR5 cell surface expression could lead to an increased pro-caspase- 8 to c-FLIP ratio in the DISC resulting in enhanced pro-caspase- 8 activation and eventually cell death. In line with this hypothesis, we detected a strong increase in pro-caspase- 8 cleavage and activity after 4 and $6 \mathrm{~h}$ treatment with TRAIL and ATO.

We also demonstrated that ATO treatment resulted in inhibition of the serine/threonine kinase Akt (Brazil et al, 2002). Furthermore, blocking the PI3K-mediated activation of Akt led to similar effects to that seen with ATO including DR5 upregulation, c-FLIP downregulation and greatly increased responsiveness to TRAIL. From these observations we conclude that inhibition of Akt is sufficient to restore TRAIL sensitivity, and the TRAIL-sensitising effect of ATO is at least in part due to inhibition of Akt. Akt is frequently activated in various cancers and moreover, high levels of phosphorylated (activated) Akt is a poor prognostic indicator in CML (Vivanco and Sawyers, 2002; Xu et al, 2003; Thompson and Thompson, 2004; Grandage et al, 2005). To promote cell survival, Akt phoshorylates and inhibits the pro-apoptotic protein $\mathrm{BAD}$, downregulates the expression of $\mathrm{Bim}$ and at the same time upregulates antiapoptotic proteins, such as c-FLIP, IAPs (inhibitor of apoptosis proteins) and Bcl-2 by activating NF- $\kappa$ B (Thompson and Thompson, 2004). Akt is also known to mediate TRAIL resistance (Nam et al, 2003). A constitutively activated Akt protected HL-60 cells (an APL cell line) from TRAIL-induced apoptosis through a mechanism involving NF- $\kappa \mathrm{B}$ activation and cFLIP $_{L}$ upregulation, all of which could be reversed by treatment with PI3K inhibitors (Bortul et al, 2003). These findings are similar to our own observations, although the authors of this report did not find any change in cell surface expression of death receptors, highlighting that the response to Akt inhibition is likely to be cell type specific.

As yet, we cannot rule out that other mechanisms also contribute to the TRAIL-potentiating effect of ATO. For example, ATO is a potent inducer of histone hyperacetylation (Perkins et al, 2000; Chen et al, 2001). While the present manuscript was in preparation, GM Cohen's lab published that histone deacetylase inhibitors, in very low concentrations, are able to sensitise TRAILresistant chronic lymphocytic leukaemia cells (Inoue et al, 2004). The mechanism they revealed involves DR5 upregulation, facilitated TRAIL receptor DISC formation and enhanced caspase-8 processing, many features similar to our findings.

In summary, our data provide for the first time a potential new usage of ATO, that is, in combination with TRAIL as an antieukemic agent. At low, easily achievable concentrations, ATO can reverse TRAIL resistance, probably in part due to inhibition of Akt. While Akt inhibitors are not yet clinically available, our results suggest that ATO, an already approved medication, can achieve the same effect and offers a combination therapy with TRAIL as a novel systemic therapy for leukaemias.

\section{ACKNOWLEDGEMENTS}

We thank Professor Wim J Quax (University of Groningen, Groningen, the Netherlands) for providing recombinant TRAIL and Dr Una Fitzgerald and Dr Ralf Zwacka for thoughtful comments and critical reading of the manuscript. This work was financially supported by the Millennium Research Fund (NUI, Galway), Higher Education Authority of Ireland and by the EU fifth framework programme (QLK3-CT-2001-00498).

\section{REFERENCES}

Aggarwal BB, Bhardwaj U, Takada Y (2004) Regulation of TRAIL-induced apoptosis by ectopic expression of antiapoptotic factors. Vitam Horm 67: $453-483$

Akay C, Gazitt Y (2003) Arsenic trioxide selectively induces early and extensive apoptosis via the APO2/caspase-8 pathway engaging the mitochondrial pathway in myeloma cells with mutant p53. Cell Cycle 2: 358-368

Almasan A, Ashkenazi A (2003) Apo2L/TRAIL: apoptosis signaling, biology, and potential for cancer therapy. Cytokine Growth Factor Rev 14: $337-348$

Ashkenazi A, Dixit VM (1999) Apoptosis control by death and decoy receptors. Curr Opin Cell Biol 11: 255-260

Bortul R, Tazzari PL, Cappellini A, Tabellini G, Billi AM, Bareggi R, Manzoli L, Cocco L, Martelli AM (2003) Constitutively active Akt1 protects HL60 leukemia cells from TRAIL-induced apoptosis through a mechanism involving NF-kappaB activation and cFLIP(L) up-regulation. Leukemia 17: $379-389$

Brazil DP, Park J, Hemmings BA (2002) PKB binding proteins. Getting in on the Akt. Cell 111: 293-303

Chen GQ, Zhu J, Shi XG, Ni JH, Zhong HJ, Si GY, Jin XL, Tang W, Li XS, Xong SM, Shen ZX, Sun GL, Ma J, Zhang P, Zhang TD, Gazin C, Naoe T, Chen SJ, Wang ZY, Chen Z (1996) In vitro studies on cellular and molecular mechanisms of arsenic trioxide $\left(\mathrm{As}_{2} \mathrm{O}_{3}\right)$ in the treatment of acute promyelocytic leukemia: $\mathrm{As}_{2} \mathrm{O}_{3}$ induces NB4 cell apoptosis with downregulation of Bcl-2 expression and modulation of PML-RAR alpha/ PML proteins. Blood 88: $1052-1061$

Chen Z, Chen GQ, Shen ZX, Chen SJ, Wang ZY (2001) Treatment of acute promyelocytic leukemia with arsenic compounds: in vitro and in vivo studies. Semin Hematol 38: 26-36

Cheng J, Haas M (1990) Frequent mutations in the p53 tumor suppressor gene in human leukemia T-cell lines. Mol Cell Biol 10: 5502-5509

Concannon CG, FitzGerald U, Holmberg CI, Szegezdi E, Sistonen L, Samali A (2005) CD95-mediated alteration in Hsp70 levels is dependent on protein stabilization. Cell Stress Chaperones 10: 59-65
Douer D, Tallman MS (2005) Arsenic trioxide: new clinical experience with an old medication in hematologic malignancies. J Clin Oncol 23: 2396-2410

Ehrhardt H, Fulda S, Schmid I, Hiscott J, Debatin KM, Jeremias I (2003) TRAIL induced survival and proliferation in cancer cells resistant towards TRAIL-induced apoptosis mediated by NF-kappaB. Oncogene 22: $3842-3852$

Evens AM, Tallman MS, Gartenhaus RB (2004) The potential of arsenic trioxide in the treatment of malignant disease: past, present, and future. Leuk Res 28: 891 - 900

Ganten TM, Haas TL, Sykora J, Stahl H, Sprick MR, Fas SC, Krueger A, Weigand MA, Grosse-Wilde A, Stremmel W, Krammer PH, Walczak H (2004) Enhanced caspase-8 recruitment to and activation at the DISC is critical for sensitisation of human hepatocellular carcinoma cells to TRAIL-induced apoptosis by chemotherapeutic drugs. Cell Death Differ 11(Suppl 1): S86-S96

Grandage VL, Gale RE, Linch DC, Khwaja A (2005) PI3-kinase/Akt is constitutively active in primary acute myeloid leukaemia cells and regulates survival and chemoresistance via NF-kB, MAPkinase and p53 pathways. Leukemia 19: 586-594

Inoue S, MacFarlane M, Harper N, Wheat LM, Dyer MJ, Cohen GM (2004) Histone deacetylase inhibitors potentiate TNF-related apoptosis-inducing ligand (TRAIL)-induced apoptosis in lymphoid malignancies. Cell Death Differ 11(Suppl 2): S193-S206

Insinga A, Monestiroli S, Ronzoni S, Gelmetti V, Marchesi F, Viale A, Altucci L, Nervi C, Minucci S, Pelicci PG (2005) Inhibitors of histone deacetylases induce tumor-selective apoptosis through activation of the death receptor pathway. Nat Med 11: 71-76

Irmler $\mathrm{M}$, Thome $\mathrm{M}$, Hahne $\mathrm{M}$, Schneider $\mathrm{P}$, Hofmann $\mathrm{K}$, Steiner $\mathrm{V}$, Bodmer JL, Schroter M, Burns K, Mattmann C, Rimoldi D, French LE, Tschopp J (1997) Inhibition of death receptor signals by cellular FLIP. Nature 388: $190-195$

Jin Z, McDonald III ER, Dicker DT, El-Deiry WS (2004) Deficient tumor necrosis factor-related apoptosis-inducing ligand (TRAIL) death 
receptor transport to the cell surface in human colon cancer cells selected for resistance to TRAIL-induced apoptosis. J Biol Chem 279: $35829-$ 35839

Juo P, Kuo CJ, Yuan J, Blenis J (1998) Essential requirement for caspase-8/ FLICE in the initiation of the Fas-induced apoptotic cascade. Curr Biol 8: $1001-1008$

Korsmeyer SJ (1992) Chromosomal translocations in lymphoid malignancies reveal novel proto-oncogenes. Annu Rev Immunol 10: 785-807

Krueger A, Schmitz I, Baumann S, Krammer PH, Kirchhoff S (2001) Cellular FLICE-inhibitory protein splice variants inhibit different steps of caspase- 8 activation at the CD95 death-inducing signaling complex. I Biol Chem 276: $20633-20640$

Lawrence D, Shahrokh Z, Marsters S, Achilles K, Shih D, Mounho B, Hillan K, Totpal K, DeForge L, Schow P, Hooley J, Sherwood S, Pai R, Leung S, Khan L, Gliniak B, Bussiere J, Smith CA, Strom SS, Kelley S, Fox JA, Thomas D, Ashkenazi A (2001) Differential hepatocyte toxicity of recombinant Apo2L/TRAIL versions. Nat Med 7: 383-385

Liu Q, Hilsenbeck S, Gazitt Y (2003) Arsenic trioxide-induced apoptosis in myeloma cells: p53-dependent G1 or G2/M cell cycle arrest, activation of caspase- 8 or caspase-9, and synergy with APO2/TRAIL. Blood 101: $4078-4087$

MacFarlane M (2003) TRAIL-induced signalling and apoptosis. Toxicol Lett 139: $89-97$

Nagane M, Huang HJ, Cavenee WK (2001) The potential of TRAIL for cancer chemotherapy. Apoptosis 6: 191-197

Nam SY, Jung GA, Hur GC, Chung HY, Kim WH, Seol DW, Lee BL (2003) Upregulation of FLIP(S) by Akt, a possible inhibition mechanism of TRAIL-induced apoptosis in human gastric cancers. Cancer Sci 94: $1066-1073$

Niu C, Yan H, Yu T, Sun HP, Liu JX, Li XS, Wu W, Zhang FQ, Chen Y, Zhou L, Li JM, Zeng XY, Yang RR, Yuan MM, Ren MY, Gu FY, Cao Q, Gu BW, Su XY, Chen GQ, Xiong SM, Zhang T, Waxman S, Wang ZY, Chen Z, Hu J, Shen ZX, Chen SJ (1999) Studies on treatment of acute promyelocytic leukemia with arsenic trioxide: remission induction, follow-up, and molecular monitoring in 11 newly diagnosed and 47 relapsed acute promyelocytic leukemia patients. Blood 94: 3315-3324

O’Dwyer ME, La Rosee P, Nimmanapalli R, Bhalla KN, Druker BJ (2002) Recent advances in Philadelphia chromosome-positive malignancies: the potential role of arsenic trioxide. Semin Hematol 39: 18-21

Perkins C, Kim CN, Fang G, Bhalla KN (2000) Arsenic induces apoptosis of multidrug-resistant human myeloid leukemia cells that express Bcr-Abl or overexpress MDR, MRP, Bcl-2, or Bcl-x(L). Blood 95: $1014-1022$

Ricci MS, Jin Z, Dews M, Yu D, Thomas-Tikhonenko A, Dicker DT, El-Deiry WS (2004) Direct repression of FLIP expression by c-myc is a major determinant of TRAIL sensitivity. Mol Cell Biol 24: 8541 8555
Rosato RR, Dai Y, Almenara JA, Maggio SC, Grant S (2004) Potent antileukemic interactions between flavopiridol and TRAIL/Apo2L involve flavopiridol-mediated XIAP downregulation. Leukemia 18: $1780-1788$

Sartorius U, Schmitz I, Krammer PH (2001) Molecular mechanisms of death-receptor-mediated apoptosis. Chembiochem 2: 20-29

Sayers TJ, Brooks AD, Koh CY, Ma W, Seki N, Raziuddin A, Blazar BR Zhang X, Elliott PJ, Murphy WJ (2003) The proteasome inhibitor PS-341 sensitizes neoplastic cells to TRAIL-mediated apoptosis by reducing levels of c-FLIP. Blood 102: 303-310

Shankar S, Srivastava RK (2004) Enhancement of therapeutic potential of TRAIL by cancer chemotherapy and irradiation: mechanisms and clinical implications. Drug Resist Update 7: 139-156

Sharp DA, Lawrence DA, Ashkenazi A (2005) Selective knockdown of the long variant of cellular FLICE-inhibitory protein augments death receptor-mediated caspase-8 activation and apoptosis. J Biol Chem 280: $19401-19409$

Sheridan JP, Marsters SA, Pitti RM, Gurney A, Skubatch M, Baldwin D, Ramakrishnan L, Gray CL, Baker K, Wood WI, Goddard AD, Godowski P, Ashkenazi A (1997) Control of TRAIL-induced apoptosis by a family of signaling and decoy receptors. Science 277: 818-821

Soignet SL, Frankel SR, Douer D, Tallman MS, Kantarjian H, Calleja E, Stone RM, Kalaycio M, Scheinberg DA, Steinherz P, Sievers EL, Coutre S, Dahlberg S, Ellison R, Warrell Jr RP (2001) United States multicenter study of arsenic trioxide in relapsed acute promyelocytic leukemia. J Clin Oncol 19: $3852-3860$

Thompson JE, Thompson CB (2004) Putting the rap on Akt. J Clin Oncol 22: $4217-4226$

Trepel M, Scheding S, Groscurth P, Horny HP, Malipiero U, Brugger W, Dichgans J, Weller M (1997) A new look at the role of p53 in leukemia cell sensitivity to chemotherapy. Leukemia 11: $1842-1849$

Vivanco I, Sawyers CL (2002) The phosphatidylinositol 3-kinase AKT pathway in human cancer. Nat Rev Cancer 2: 489-501

Walczak H, Bouchon A, Stahl H, Krammer PH (2000) Tumor necrosis factor-related apoptosis-inducing ligand retains its apoptosis-inducing capacity on Bcl-2- or Bcl-xL-overexpressing chemotherapy-resistant tumor cells. Cancer Res 60: 3051 - 3057

Wang S, El-Deiry WS (2003) Requirement of p53 targets in chemosensitization of colonic carcinoma to death ligand therapy. Proc Natl Acad Sci USA 100: $15095-15100$

Wiley SR, Schooley K, Smolak PJ, Din WS, Huang CP, Nicholl JK, Sutherland GR, Smith TD, Rauch C, Smith CA, Raymond GG (1995) Identification and characterization of a new member of the TNF family that induces apoptosis. Immunity 3: 673-682

$\mathrm{Xu}$ Q, Simpson SE, Scialla TJ, Bagg A, Carroll M (2003) Survival of acute myeloid leukemia cells requires PI3 kinase activation. Blood 102: $972-980$ 